\title{
Assessing the Economic Impact of Inversion Tillage, Cover Crops, and Herbicide Regimes in Palmer Amaranth (Amaranthus palmeri) Infested Cotton
}

\author{
Leah M. Duzy, ${ }^{1}$ Andrew J. Price, ${ }^{1}$ Kipling S. Balkcom, ${ }^{1}$ and Jatinder S. Aulakh ${ }^{2}$ \\ ${ }^{1}$ National Soil Dynamics Laboratory, Agricultural Research Service, United States Department of Agriculture, \\ 411 South Donahue Drive, Auburn, AL 36852, USA \\ ${ }^{2}$ The Connecticut Agricultural Experiment Station, Valley Laboratory, 153 Cook Hill Road, P.O. Box 248, Windsor, CT 06095, USA \\ Correspondence should be addressed to Leah M. Duzy; leah.duzy@ars.usda.gov
}

Received 26 July 2016; Revised 7 October 2016; Accepted 2 November 2016

Academic Editor: Patrick J. Tranel

Copyright (c) 2016 Leah M. Duzy et al. This is an open access article distributed under the Creative Commons Attribution License, which permits unrestricted use, distribution, and reproduction in any medium, provided the original work is properly cited.

\begin{abstract}
Cotton (Gossypium hirsutum L.) producers in Alabama are faced with a rapidly expanding problem that decreases yields and increases production costs: herbicide-resistant weeds. Producers increasingly rely on integrated weed management strategies that raise production costs. This analysis evaluated how tillage, cover crops, and herbicide regime affected net returns above variable treatment costs (net returns) for cotton production in Alabama from 2009 to 2011 under pressure from Palmer amaranth (Amaranthus palmeri S. Wats.). Annual net returns were compared for two tillage treatments (inversion and noninversion tillage), three cover crops (crimson clover [Trifolium incarnatum L.], cereal rye [Secale cereal L.], and winter fallow), and three herbicide regimes (PRE, POST, and PRE+POST). Results indicate that under heavy Palmer amaranth population densities one year of inversion tillage followed by two years of noninversion tillage, along with a POST or PRE+POST herbicide application had the highest net returns in the first year; however, the economic benefit of inversion tillage, across all herbicide treatments, was nonexistent in 2010 and 2011. Cotton producers with Palmer amaranth infestations would likely benefit from cultural controls, in conjunction with herbicide applications, as part of their weed management system to increase net returns.
\end{abstract}

\section{Introduction}

In the southern United States (US), producers spent over 37 billion US\$ on crop production expenses in 2015. Agricultural chemicals and seed comprised over 4 billion US\$ or $11 \%$ of total crop production expenses. In Alabama, total operating expenses for farms classified as cotton farms (North American Industry Classification System [NAICS] 11192) equaled 127.6 million US\$ as of the 2012 Census of Agriculture. Of that, producers spent 22.29 million US\$ $(17.5 \%)$ on pesticides and other chemicals and 19.75 million US\$ (15.5\%) on seed [1], which included expenses such as costs of seed, seed treatments, and seed cleaning costs [2]. While many per unit production costs are beyond the control of the producer (i.e., cost of fuel per liter), producers can control the amount and types of inputs used on their operations.
Since the commercial introduction of glyphosateresistant cotton in 1997 and subsequent introduction of other herbicide-resistant cotton varieties (i.e., glufosinate-resistant cotton in 2004), adoption of herbicide-resistant cotton has been widespread. In 2014, 98\% of upland cotton hectares in Alabama were seeded to biotechnology varieties of cotton: $9 \%$ to insect resistant only varieties, $6 \%$ to herbicide resistant only varieties, and $83 \%$ to stacked trait (more than one genetically engineered trait) varieties [3]. With the adoption of herbicide-resistant varieties, cotton producers have reduced weed management costs by reducing the number of herbicide applications and many have moved to a conservation tillage system $[4,5]$. Unfortunately, cotton producers in Alabama and across the Cotton Belt are faced with a rapidly expanding problem that reduces yields and increases production costs: herbicide-resistant weeds. 
Currently, three glyphosate-resistant weed species have been reported in Alabama: Palmer amaranth (Amaranthus palmeri S. Wats.), horseweed (Conyza canadensis (L.) Cronq.), and common ragweed (Ambrosia artemisiifolia L.) [6].

While the hectarage impacted by all three herbicideresistant weeds continues to increase, cotton producers in Southeast and Mid-South US are fighting a difficult battle against herbicide-resistant Palmer amaranth, a highly aggressive, drought-tolerant weed that grows rapidly and is a prolific seed producer [7-9]. Herbicide-resistant Palmer amaranth is considered the most troublesome weed species for cotton producers in the Southeast and Mid-South US [10-12]. To address this challenging weed, producers are reverting to management practices that increase their production costs, such as additional herbicide treatments, inversion tillage, and hand weeding [4]. Sosnoskie and Culpepper [10] found that producers in Georgia have increased the use of herbicides, hand weeding, and mechanical weed control (i.e., inversion tillage after harvest) as part of their weed management systems to address Palmer amaranth infestations in their fields. Managing Palmer amaranth through conventional tillage is a threat to the over 44 thousand hectares of no-till and strip-till acres on operations classified as cotton farms (NAICS 11192) in Alabama [1,5]. An additional option that may help maintain conservation tillage hectares is to move to a glufosinate-based system, which has shown success in controlling glyphosate-resistant Palmer amaranth $[13,14]$.

Recent literature suggests that the use of cultural practices, such as cover crops and tillage, may be necessary for optimal control of Palmer amaranth [5, 15-17]. While there is literature on the agronomic impacts of Palmer amaranth, such as yield loss and decreased harvest efficiency [11, 18], there is limited information on the effect of different weed management strategies on net returns. DeVore et al. [16] acknowledge the need to understand economic benefits of combining inversion tillage and cover crops to address Palmer amaranth infestations; however, the authors only discuss production costs associated with control. As part of a six-part benchmark study on glyphosate-resistant cropping systems, Weirich et al. [19] conclude that producers can adopt more intensive herbicide management to control glyphosate resistant weeds and recognize equivalent net returns in the short-term; however, the authors did not consider cultural practices, aside from crop rotation, as part of the intensive herbicide management strategies. Shurley et al. [20] investigated the use of a high biomass rye cover crop to control glyphosate-resistant Palmer amaranth in Georgia. Their findings indicated the highest net returns were achieved in treatments with no cover crop instead of a rye cover crop, which they attributed to lower production costs for the no cover crop treatment. In Alabama, Price et al. [21] found that a conservation agriculture system (which includes a high residue rye cover crop and conservation tillage using a subsoiler and no-till planter) increased cotton net returns over conventional tillage in two out of three years under heavy pressure from Palmer amaranth and redroot pigweed (Amaranthus retroflexus L.).

Although previous research with different production systems for Palmer amaranth control has shown mixed results, there is limited information on the effect of different weed management strategies on net returns. The objective of this analysis was to evaluate the effect of tillage, cover crops, and herbicide regimes on net returns above variable treatment costs in glufosinate-resistant cotton production systems in Alabama to manage severe Palmer amaranth infestations.

\section{Materials and Methods}

Field experiments were conducted from 2009 to 2011 at the E. V. Smith Research Center, Field Crops Unit (EVS) near Shorter, Alabama ( $\left.32 \mathrm{~N} 25^{\prime} 28.95^{\prime \prime}, 85 \mathrm{~W} 53^{\prime} 27.31^{\prime \prime}\right)$. The soil at this site was a Compass sandy loam (coarse-loamy, siliceous, subactive, thermic Plinthic Paleudults). The experiment was conducted on a site that had been in continuous strip-till for six years prior to the establishment of the experiment in fall 2008. The schedule of operations is displayed in Table 1 .

The site was infested with naturally occurring resistant and susceptible Palmer amaranth, and, to guarantee a sizeable seedbank, approximately 28 million native glyphosate susceptible Palmer amaranth seeds were broadcast per hectare. A randomized complete block design with a split-split plot treatment restriction was used in each year of the experiment. The main plots were two soil-inversion treatments: fall inversion tillage (IT) and noninversion tillage (NIT) administered in the spring. The subplots were three cover crops: crimson clover (clover), cereal rye (rye), and winter fallow (fallow). The sub-subplots were three herbicide regimes: preemergence (PRE) alone, postemergence (POST) alone, and PRE+POST (Table 2).

A no herbicide check was included in the original experiment but was excluded from this analysis due to lack of weed control variability within treatments and lack of yield data. The main, sub, and sub-subplots were 43.9 by 9 m, 14.6 by 9 m, and 3.6 by $9 \mathrm{~m}$, respectively. Treatments were replicated three times; however, they were not rerandomized each year due to the tillage treatment.

2.1. Tillage and Cover Crop Treatments. The IT treatment consisted of one pass with a moldboard plow $(30 \mathrm{~cm})$ immediately followed by ( $\mathrm{fb}$ ) one pass with a disk and one pass with a cultivator in fall 2008. In the following years, the IT plots were managed the same as the NIT plots. Each year in the spring, the IT and NIT plots were subsoiled prior to planting with an in-row subsoiler equipped with pneumatic tires behind the shank. Each preceding fall, rye and clover cover crops were planted using 101 and $28 \mathrm{~kg} \mathrm{ha}^{-1}$ of seed, respectively. For rye, the var. "Elbon" was planted in 2009 and 2010 and, in 2011, the var. "Wrens Abruzzi" was planted due to seed availability. For clover, the var. "Dixie" was planted in all three years. The rye treatment was not fertilized in 2009 and 2010; however, it was fertilized with $67 \mathrm{~kg} \mathrm{~N} \mathrm{ha}^{-1}$ as a 33-0-0 granular fertilizer in 2011. In 2011, the clover treatment was replanted in early March due to establishment failure of the original planting. Winter weeds were allowed to grow over the winter in the fallow treatment. 
TABLE 1: Schedule of operations ${ }^{\mathrm{a}}$.

\begin{tabular}{|c|c|c|c|}
\hline \multirow{2}{*}{ Operations } & \multicolumn{3}{|c|}{ Experiment years } \\
\hline & $2008 / 2009$ & $2009 / 2010$ & $2010 / 2011$ \\
\hline Broadcasting Palmer amaranth seed & $19 \mathrm{Nov}$ & & \\
\hline Fall inversion tillage & 19 Nov & & \\
\hline Cover crop planting & $20 \mathrm{Nov}$ & 6 Jan & $2 \mathrm{Dec}$ \\
\hline Cover crop (rye) fertilization & - & - & $14 \mathrm{Feb}$ \\
\hline Cover crop (clover) replant & - & - & 3 Mar \\
\hline Winter burn down (fallow) & - & - & 31 Mar \\
\hline Rolling and termination of cover crops & $22 \mathrm{Apr}$ & 18 May & $19 \mathrm{Apr}$ \\
\hline Subsoiling & $23 \mathrm{Apr}$ & 24 May & $26 \mathrm{Apr}$ \\
\hline Cotton planting & 1 Jun & 27 May & 5 May \\
\hline Cotton fertilization & 1 Jun & 27 May & 5 May \\
\hline PRE application & 3 Jun & 27 May & 6 May \\
\hline POST application & 16 Jun & 16 Jun & 24 May \\
\hline Additional POST application & - & - & 13 June \\
\hline Graminicide application & 13 July & 8 July & 6 July \\
\hline LAYBY application & 14 Aug & 16 Aug & 19 July \\
\hline Cotton defoliation & 26 Oct & $14 \mathrm{Oct}$ & 13 Sep \\
\hline Cotton harvesting & $9 \mathrm{Nov}$ & $20 \mathrm{Oct}$ & 30 Sep \\
\hline
\end{tabular}

${ }^{a}$ Schedule of operations adapted from Aulakh et al. [15].

TABLE 2: Description of herbicide treatments.

\begin{tabular}{|c|c|c|c|}
\hline Herbicide regime & Chemical & & $\begin{array}{c}\text { Rate } \\
\mathrm{kg} \mathrm{ai} \mathrm{ha}^{-1}\end{array}$ \\
\hline \multirow{2}{*}{$\mathrm{PRE}^{\mathrm{a}}$} & Pendimethalin & Prowl $^{\circledR}$, BASF Ag. Products, Research Triangle Park, NC, USA & 0.84 \\
\hline & Fomesafen & Reflex $^{\circledR}$, Syngenta Crop Protection, Inc. Greensboro, NC, USA & 0.28 \\
\hline \multirow{2}{*}{$\mathrm{POST}^{\mathrm{b}}$} & Glufosinate & Ignite, Bayer Crop Science, Research Triangle Park, NC, USA & 0.60 \\
\hline & S-Metolachlor & Dual II Magnum ${ }^{\circledR}$, Syngenta Crop Protection, Inc., Greensboro, NC, USA & 0.54 \\
\hline \multirow{4}{*}{$\mathrm{PRE}+\mathrm{POST}^{\mathrm{b}}$} & Pendimethalin & Prowl, BASF Ag. Products, Research Triangle Park, NC, USA & 0.84 \\
\hline & Fomesafen & Reflex, Syngenta Crop Protection, Inc. Greensboro, NC, USA & 0.28 \\
\hline & Glufosinate & Ignite, Bayer Crop Science, Research Triangle Park, NC, USA & 0.60 \\
\hline & S-Metolachlor & Dual II Magnum, Syngenta Crop Protection, Inc., Greensboro, NC, USA & 0.54 \\
\hline \multirow{3}{*}{ LAYBY } & Prometryn & Caporal ${ }^{\circledR}$, Syngenta Crop Protection, Inc., Greensboro, NC, USA & 0.84 \\
\hline & MSMA & Drexel Chemical Company, Memphis, TN, USA & 1.4 \\
\hline & Sethoxydim & Poast Plus ${ }^{\circledR}$, BASF Ag. Products, Research Triangle Park, NC, USA & 0.28 \\
\hline
\end{tabular}

${ }^{a}$ PRE herbicides were applied using $145 \mathrm{~L} \mathrm{ha}^{-1}$ of water carrier delivered through a $\mathrm{CO}_{2}$-pressurized backpack sprayer with 8002 flat-fan nozzles. POST herbicides were applied 15 to 20 days after planting cotton to 3 to 4 leaves of Palmer amaranth using $145 \mathrm{~L} \mathrm{ha}^{-1}$ delivered through an ATV-mounted sprayer with 8002 flat-fan spray nozzles.

${ }^{\mathrm{b}}$ In 2011, a second POST application glufosinate $\left(0.60 \mathrm{~kg}_{\text {ai ha }}{ }^{-1}\right)$ was made to the POST and PRE+POST treatments for added weed control.

In the spring, cover crops (including fallow) were terminated using mechanical and chemical termination methods. A three-section straight bar roller/crimper (Bigham Brothers, Inc., Lubbock, TX, USA) was used to roll the cover crops in all three years (and fallow treatments in 2009 and 2010) followed by a chemical application of a mixture of $0.84 \mathrm{~kg} \mathrm{ae} \mathrm{ha}^{-1}$ of glyphosate (Roundup Weathermax ${ }^{\circledR}$, Monsanto Company, St. Louis, MO, USA) plus $0.49 \mathrm{~kg} \mathrm{ae} \mathrm{ha}^{-1}$ of glufosinate (Ignite $^{\circledR}$, Bayer Crop Science, Research Triangle Park, NC, USA). Mechanical termination on fallow treatments was not necessary in 2011 since the fallow treatments received a winter burndown application of glufosinate $\left(0.49 \mathrm{~kg} \mathrm{ae} \mathrm{ha}^{-1}\right)$ and glyphosate $\left(0.84 \mathrm{kgae} \mathrm{ha}^{-1}\right)$ on March 31 . Due to delayed cover crop planting in fall 2009, cover crops were terminated a month later in 2010 than in 2009 and 2011. After cover crop termination and spring tillage operations, the following glufosinate-resistant cotton varieties were planted: FM 1845 LLB2 in 2009 and FM 1735 LL in 2010 and 2011 (Bayer Crop Science, Research Triangle Park, NC, US). Cotton received an application of $101 \mathrm{~kg} \mathrm{~N} \mathrm{ha}^{-1}\left(34 \mathrm{~kg} \mathrm{~N} \mathrm{ha}^{-1}\right.$ as a starter fertilizer and $67 \mathrm{~kg} \mathrm{Nha}^{-1}$ at the 8 to 10 leaf stage) each year.

2.2. Herbicide Treatments. The three herbicide treatments included in the study were PRE only, POST only, and 
TABLE 3: Production costs (US\$ $\mathrm{ha}^{-1}$ ) for cotton production by year.

\begin{tabular}{|c|c|c|c|}
\hline \multirow[t]{2}{*}{ Production item } & \multicolumn{3}{|c|}{$\begin{array}{c}\text { Production cost } \\
\text { US } \$ \mathrm{ha}^{-1}\end{array}$} \\
\hline & 2009 & 2010 & 2011 \\
\hline \multicolumn{4}{|l|}{ Production costs differing by treatment } \\
\hline \multicolumn{4}{|l|}{ Tillage $^{\mathrm{a}}$} \\
\hline NIT & 15.39 & 15.39 & 15.39 \\
\hline IT & 78.57 & 15.39 & 15.39 \\
\hline \multicolumn{4}{|l|}{ Cover crop ${ }^{\mathrm{b}}$} \\
\hline Clover & 187.63 & 187.63 & 375.27 \\
\hline Rye & 177.75 & 177.75 & 237.82 \\
\hline Fallow & 64.85 & 64.85 & 109.25 \\
\hline \multicolumn{4}{|l|}{ Herbicide regime $e^{c}$} \\
\hline PRE & 40.62 & 40.62 & 40.62 \\
\hline POST & 64.49 & 64.49 & 112.05 \\
\hline $\mathrm{PRE}+\mathrm{POST}$ & 105.11 & 105.11 & 152.67 \\
\hline \multicolumn{4}{|l|}{ Production costs based on yield } \\
\hline Ginning and warehousing (US\$ $\mathrm{kg}^{-1}$ ) & & 0.045 & \\
\hline Classing and promotion fee (US\$ $\mathrm{kg}^{-1}$ ) & & 0.003 & \\
\hline
\end{tabular}

${ }^{a}$ Inversion tillage (IT) was performed in 2009 only. In 2010 and 2011 the cost for tillage for all treatments was the cost of noninversion tillage (NIT).

${ }^{\mathrm{b}}$ Clover is crimson clover; rye is cereal rye; fallow is winter fallow. In 2011, clover was replanted and rye was only fertilized in 2011. Fallow received an additional application of glyphosate and glufosinate as a winter burndown. ${ }^{c}$ POST and PRE+POST received an additional POST application of glufosinate in 2011 .

PRE+POST. Table 2 outlines the herbicide regimes for each treatment. A last application (LAYBY) directed spray was applied each year to all plots. In 2011, the POST and PRE+POST treatments received an additional application of glufosinate $\left(0.6 \mathrm{~kg}_{\text {ai ha }}{ }^{-1}\right)$ on June 13 due to extensive Palmer amaranth growth. These plots would not have been harvestable if not for the second POST application. Additional discussion on the experiment, as well as results related to cover crop biomass, Palmer amaranth density and control, and cotton yield, are found in Aulakh et al. [15].

2.3. Economic Analysis. For the purposes of this analysis, net returns above variable treatment costs (net returns) were defined as the difference between revenues and cotton production costs (US\$ ha ${ }^{-1}$ ) associated with each treatment. Revenues were calculated based on cotton lint and cottonseed yields and prices. Since the seed cotton was not ginned, the assumed ginning percentage was $40 \%$, and cotton fiber quality was not considered in this analysis. Cotton lint (1.76 US\$ kg-1) and cottonseed (241.46 US\$ tonne ${ }^{-1}$ ) prices used in the analysis were the average cotton lint and cottonseed prices received by Alabama producers in 2013 [1]. Prices were assumed constant across all three years of the analysis.

Production costs associated with tillage, cover crop establishment and termination, and herbicide regimes (Table 3) were adapted from machinery cost estimates [22] and cotton enterprise budgets $[23,24]$. Input prices were assumed to represent prices paid by producers in 2013. Two types of production costs were considered: costs that differed by tillage, cover crop, and herbicide regime, and yield varying costs. Aside from production expenses related to treatments, all other production expenses were assumed constant across the experimental plots. Costs associated with tillage, cover crop management (fertilizer, seed, planting, and termination), herbicide regime, and interest on operating capital varied by treatment and year. Machinery costs included only variable costs (fuel, labor, and repairs and maintenance). Yield varying costs included a ginning and warehousing fee and a classing and promotion fee. Land rent, crop insurance, and fixed expenses, such as depreciation and management costs, can differ substantially between producers. Therefore, these expenses were not included in this analysis.

2.4. Statistical Analysis. Data were analysed using PROC GLIMMIX in SAS (SAS Institute, Inc., Cary, NC, USA). Dependent variables were net returns measured in US $\$ \mathrm{ha}^{-1}$. Year, tillage, cover crop, herbicide regime, and their interactions were considered fixed effects. Replication, the interaction between replication and tillage, and the interaction between replication and cover crop within tillage were considered the random effects. For net returns, year, year by tillage, year by cover crop, and year by herbicide effects were highly significant (not shown). Therefore, data were analysed by year in the final analysis. As previously stated, the no herbicide treatment was not included in the final analysis due to lack of variability (multiple replications with zero yields in the same treatment and year) in the existing data. Fisher's protected least significant difference (LSD) test at the $P=0.05$ level of significance was used to separate treatment means.

\section{Results and Discussion}

The cotton lint yield within years and across years varied greatly (Table 4), which directly influenced the variability of net returns within year and across years (Table 4). The year with the greatest yield and net return variability was 2009, followed by 2011. Although treatments were approximately the same each year (with exceptions outlined in Section 2.1), weather and timing of operations differed between years. Cumulative precipitation and growing degree days (GDD) were calculated by summing the daily precipitation and GDD days from planting to harvest each year at EVS. Growing degree days (GDD) were calculated using a base temperature of $15.56^{\circ} \mathrm{C}$. Cumulative precipitation during the cotton growing season was the highest in 2009. Total rainfall amounts were similar in 2010 and 2011; however, the timing of rainfall events was very different (Figure 1). Cumulative GDD was the lowest for 2009, followed by 2011 and 2010 (Figure 2). In 2009, the cool, wet weather at the end of the growing season heavily influenced cotton yields and subsequently net returns. The below normal temperatures and above average rainfall continued into fall of 2009 and winter of 2010 impacting cover crop planting and growth.

The timing of operations differed each year, specifically related to cover crop planting and termination and cotton planting and harvesting (Table 1). Producers are often faced 
TABLE 4: Summary statistics for cotton lint yield $\left(\mathrm{kg} \mathrm{ha}^{-1}\right)$ and net returns (US\$ ha $\left.{ }^{-1}\right)$.

\begin{tabular}{cccccccccc}
\hline Year & Mean & Maximum & $\begin{array}{c}\text { Cotton lint yield } \\
\text { Minimum } \\
\mathrm{kg} \mathrm{ha}^{-1}\end{array}$ & CV & Regional average & Mean & $\begin{array}{c}\text { Net returns to cotton production } \\
\text { Maximum } \\
\text { Minimum } \$ \text { ha }^{-1}\end{array}$ & CV \\
\hline 2009 & 455 & 1193 & 49 & 69 & 638 & 584 & 1890 & -118 & 94 \\
2010 & 512 & 824 & 130 & 27 & 609 & 722 & 1225 & 53 & 34 \\
2011 & 1057 & 1447 & 640 & 17 & 836 & 1594 & 2420 & 856 \\
\hline
\end{tabular}

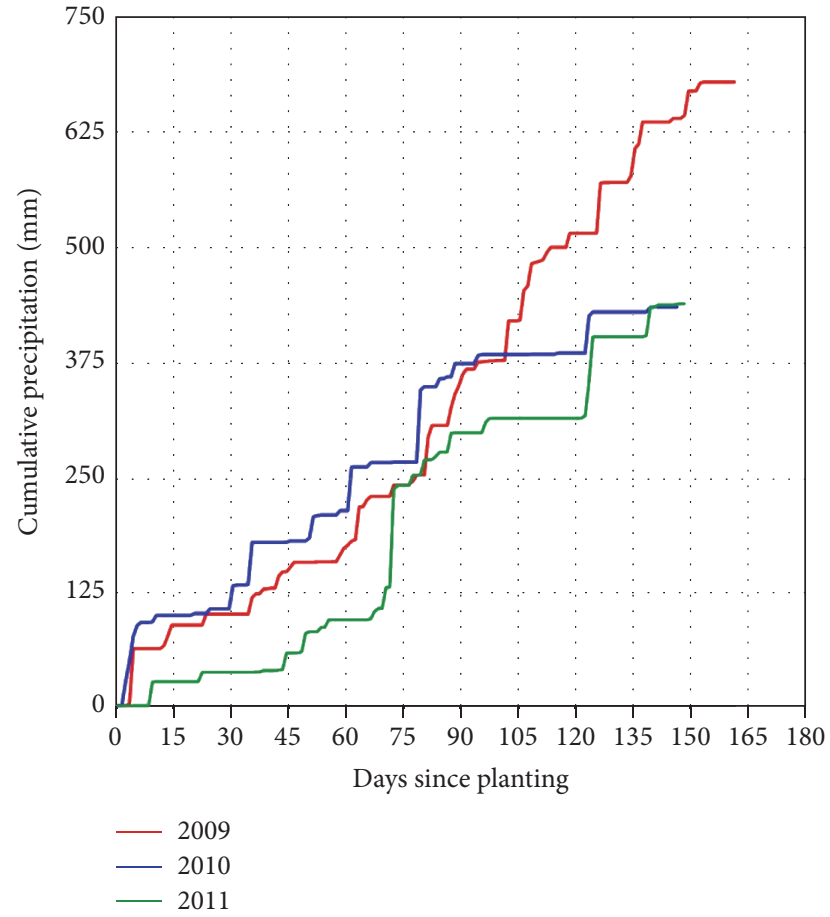

FIGURE 1: Cumulative precipitation $(\mathrm{mm})$ for days since planting at E. V. Smith Research Center from 2009 to 2011.

with similar constraints, such as labor shortages or weather delays, which can negatively influence the economic benefits of cover crops through increased costs or less biomass production. Cover crops were planted in mid-November, 2008; however, cover crops were planted in early January, 2010, for crop year 2010 and December, 2010, for crop year 2011, due to late harvest of the previous cash crop. While rye can be established in very cool weather, temperatures of $3.33^{\circ} \mathrm{C}$ are required for vegetative growth and the recommended planting date is late September to early November [25]. Previous research demonstrates that planting date of rye influences the amount of rye biomass produced and performance of the cover crop as part of the system [21]. For clover, the recommended planting date is even earlier, from August to September [25]. As previously mentioned, clover in 2011 was replanted in March due to lack of vegetative growth; however this was only 47 days prior to cover crop termination. Replanting clover in 2011 increased the establishment costs associated with the clover treatments as compared to the other treatments.

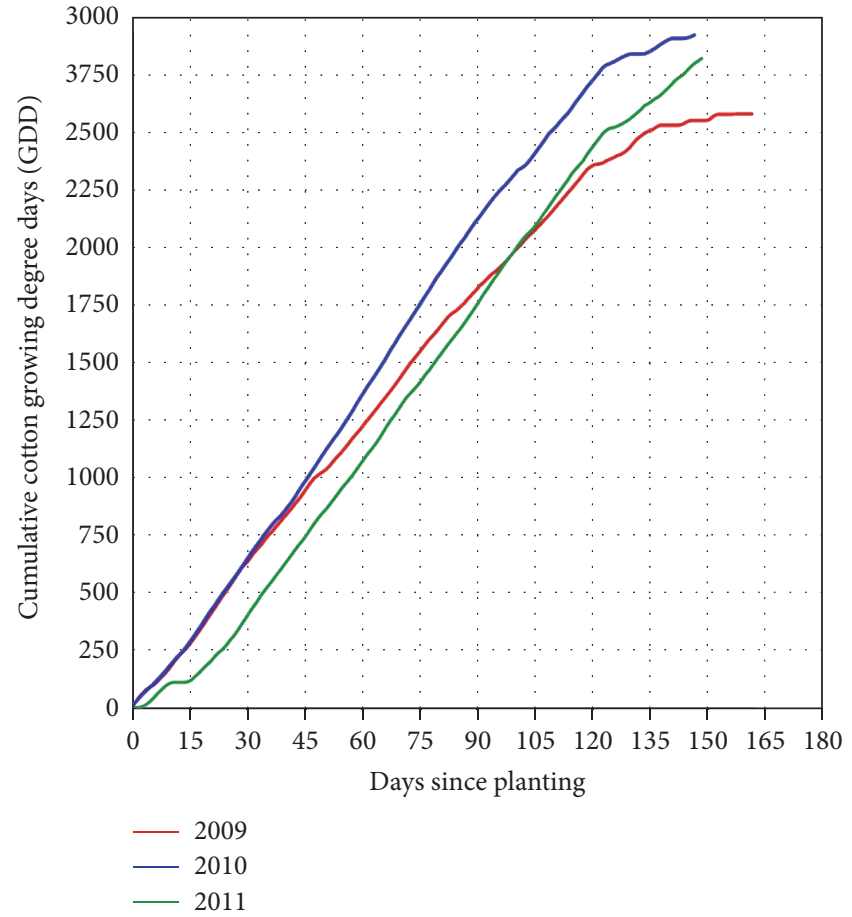

Figure 2: Cumulative growing degree days (GDD) for cotton for days since planting at E. V. Smith Research Center from 2009 to 2011.

Normal cotton progress in Alabama includes planting between early April and mid-June and harvesting between early September and mid-December. Cotton was planted within this range each year; however, in 2009, cotton was planted towards the end of the range (71 days after April 1). In 2009, due to a major rain event at the end of the growing season, cotton harvest was delayed until the second week of November (161 days after planting) as compared to the end of October in 2010 (146 days after planting) and the end of September in 2011 (148 days after planting). Differences in schedules of operations between years may explain the variability of yields and net returns across years [21, 26-28]. Across all treatments, 2011 was the only year with average cotton lint yields above the corresponding agricultural district average [1]. In 2009 and 2010, the average experimental yield was approximately $39 \%$ and $12 \%$ lower than the average agricultural district yield, respectively (Table 4). EVS is located in the Black Belt Agricultural District (D40), as defined by USDA [1]. In Alabama, average agricultural district yields are 
TABLE 5: Analysis of variance and variance-component estimates for the net returns from cotton production by year.

\begin{tabular}{|c|c|c|c|c|c|c|c|c|c|}
\hline \multirow{2}{*}{ Fixed effects } & \multicolumn{3}{|c|}{2009} & \multicolumn{3}{|c|}{2010} & \multicolumn{3}{|c|}{2011} \\
\hline & $\mathrm{DF}^{\mathrm{a}}$ & $F$ value & $\operatorname{Pr}>F$ & DF & $F$ value & $\operatorname{Pr}>F$ & DF & $F$ value & $\operatorname{Pr}>F$ \\
\hline Tillage & 1,10 & 31.29 & $<0.001$ & 1,2 & 0.02 & 0.909 & 1,4 & 0.25 & 0.646 \\
\hline Cover & 2,10 & 2.92 & 0.100 & 2,8 & 1.35 & 0.312 & 2,8 & 9.79 & 0.007 \\
\hline Tillage $*$ cover & 2,10 & 0.82 & 0.468 & 2,8 & 0.92 & 0.435 & 2,8 & 0.04 & 0.960 \\
\hline Herbicide & 2,24 & 13.14 & 0.0001 & 2,24 & 2.19 & 0.134 & 2,24 & 0.22 & 0.806 \\
\hline Tillage $*$ herbicide & 2,24 & 4.09 & 0.030 & 2,24 & 3.39 & 0.051 & 2,24 & 2.01 & 0.156 \\
\hline Cover $*$ herbicide & 4,24 & 1.95 & 0.134 & 4,24 & 2.01 & 0.126 & 4,24 & 1.15 & 0.356 \\
\hline Tillage $*$ cover $*$ herbicide & 4,24 & 2.02 & 0.123 & 4,24 & 1.40 & 0.263 & 4,24 & 1.67 & 0.190 \\
\hline Random effects & & Estimate & Std. err. & & Estimate & Std. err. & & Estimate & Std. err. \\
\hline Rep & & 24446 & 34715 & & 3128 & 13900 & & 0 & 0 \\
\hline Rep $*$ tillage & & 0 & 0 & & 8129 & 16781 & & 67626 & 55729 \\
\hline Rep $*$ cover (tillage) & & 33428 & 27832 & & 13962 & 12594 & & 19791 & 16627 \\
\hline Residual & & 79268 & 22883 & & 31465 & 9083 & & 37953 & 10956 \\
\hline
\end{tabular}

${ }^{\mathrm{a}}$ Numerator degrees of freedom, denominator degrees of freedom.

not separated by irrigated and nonirrigated acres. Therefore, the average includes higher irrigated yields, along with lower nonirrigated yields. Furthermore, the weed pressure in the experiment may have been more severe than the weed pressure in the average field in the Black Belt Agricultural District. For these reasons, the average experimental yield may be less than the average agricultural district yield.

Data were analysed across years, and interactions between year and treatment (tillage, cover crop, and herbicide regime) were all significant at $P \leq 0.05$ (not shown). Therefore, data were analysed by year. The analysis of variance (Table 5) shows fixed and random effects by year.

3.1. Herbicide Regime. Herbicide regime had a significant effect on net returns in one out of three years (Tables 5 and 6). In 2009, applying PRE+POST instead of PRE alone or POST alone increased net returns by 481 and $228 \mathrm{US} \$ \mathrm{ha}^{-1}$, respectively. Applying POST alone instead of

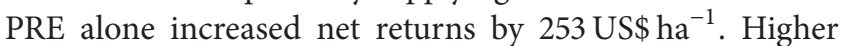
net returns for PRE+POST were due to increased Palmer amaranth control resulting in higher cotton lint yields [15]. Adopting PRE+POST increased herbicide production costs by $64 \mathrm{USS} \mathrm{ha}^{-1}$ over PRE, or a yield equivalent of $37 \mathrm{~kg} \mathrm{ha}^{-1}$. The yield increase due to PRE+POST as compared to PRE alone, all else held equal, was over $290 \mathrm{~kg} \mathrm{ha}^{-1}$. While there was no statistical difference $(P=0.05)$ between any of the herbicide regimes in 2010 and 2011, PRE+POST had the highest numerical net returns in both years.

3.2. Tillage by Herbicide Interaction. The tillage by herbicide interaction was significant in one out of three years (Tables 5 and 7). A closer examination of this interaction revealed in 2009 that IT/PRE+POST had the highest net returns and NIT/POST had the lowest net returns; however, the following years, NIT/PRE was the most profitable treatment (Table 6). There was little significant difference outside of 2009, partially due to lower yield variability. In 2009, net
TABLE 6: Influence of tillage, cover crop, and herbicide treatments on net returns (US\$ ha ${ }^{-1}$ ) by year.

\begin{tabular}{lccc}
\hline Treatment & 2009 & $\begin{array}{c}2010 \\
\text { US\$ ha }\end{array}$ & 2011 \\
\hline $\begin{array}{l}\text { Tillage system } \\
\quad \text { a }\end{array}$ & 261 & 716 & 1650 \\
$\quad$ Noninversion & 906 & 729 & 1537 \\
$\quad$ Inversion & 257 & NS & NS \\
$\quad$ LSD $(\alpha=0.05)^{\mathrm{b}}$ & & & \\
Cover crop & 780 & 804 & 1432 \\
$\quad$ Clover & 504 & 660 & 1492 \\
Rye & 468 & 703 & 1857 \\
Fallow & $\mathrm{NS}$ & $\mathrm{NS}$ & 240 \\
LSD $(\alpha=0.05)$ & & & \\
Herbicide regimes & 339 & 755 & 1576 \\
PRE & 592 & 651 & 1587 \\
POST & 820 & 761 & 1618 \\
PRE+POST & 194 & NS & NS \\
LSD $(\alpha=0.05)$ & & & \\
\hline
\end{tabular}

${ }^{a}$ The inversion tillage (IT) treatment consisted of one pass with a moldboard plow immediately followed by one pass with a disk and one pass with a cultivator in fall 2008. In 2010 and 2011, the IT plots were managed the same as the noninversion (NIT) plots. The IT and NIT plots were subsoiled each spring prior to planting.

${ }^{\mathrm{b}}$ LSD (least significant difference) for comparing any two means within year. NS is not significant.

returns from IT/PRE+POST were eight times larger than NIT/PRE. Furthermore, net returns from IT/PRE+POST were two times larger than net returns from NIT/PRE+POST and IT/PRE. These results clearly show the variability in net returns in 2009 across tillage by herbicide regime treatments due to high concentrations of Palmer amaranth and more effective control using IT and PRE+POST [15]. Additionally, net returns in 2009 were heavily influenced by lower yields due to cooler, wetter weather during the growing season and at harvest, as compared to 2010 and 2011. 
TABLE 7: Influence of tillage system by herbicide interaction on net returns (US\$ ha ${ }^{-1}$ ) by year.

\begin{tabular}{|c|c|c|c|c|}
\hline \multirow{3}{*}{$\begin{array}{l}\text { Tillage system } \\
\text { treatment }^{\mathrm{a}}\end{array}$} & \multicolumn{4}{|c|}{ Herbicide regime } \\
\hline & PRE & POST & PRE+POST & $\operatorname{LSD}(\alpha=0.05)^{\mathrm{b}}$ \\
\hline & \multicolumn{4}{|c|}{ US\$ ha ${ }^{-1}$} \\
\hline \multicolumn{5}{|c|}{2009} \\
\hline Noninversion & 132 & 123 & 529 & \multirow{3}{*}{274} \\
\hline Inversion & 546 & 1062 & 1111 & \\
\hline \multirow{2}{*}{\multicolumn{5}{|c|}{$\operatorname{LSD}(\alpha=0.05)^{\mathrm{c}}$}} \\
\hline & & & & \\
\hline Noninversion & 836 & 612 & 699 & \multirow{3}{*}{173} \\
\hline Inversion & 674 & 690 & 824 & \\
\hline \multirow{2}{*}{\multicolumn{5}{|c|}{$\operatorname{LSD}(\alpha=0.05)$}} \\
\hline & & & & \\
\hline Noninversion & 1708 & 1602 & 1641 & \multirow{3}{*}{ NS } \\
\hline Inversion & 1445 & 1571 & 1594 & \\
\hline $\operatorname{LSD}(\alpha=0.05)$ & & NS & & \\
\hline
\end{tabular}

${ }^{a}$ The inversion tillage (IT) treatment consisted of one pass with a moldboard plow immediately followed by one pass with a disk and one pass with a cultivator in fall 2008. In 2010 and 2011, the IT plots were managed the same as the noninversion (NIT) plots. The IT and NIT plots were subsoiled each spring prior to planting.

${ }^{\mathrm{b}}$ LSD (least significant difference) for comparing any two means within tillage treatment. NS is not significant.

${ }^{c}$ LSD for comparing any two means within herbicide regime and across tillage and herbicide regime.

In 2010, the tillage by herbicide interaction was not significant $(P=0.051)$ and post hoc tests (LSD) indicated a significant difference within tillage treatment. Noninversion tillage with a PRE herbicide regime (NIT/PRE) had net returns $223.59 \mathrm{US}_{\mathrm{O}} \mathrm{ha}^{-1}$ greater than NIT/POST. The lack of statistical difference between treatments in 2011 may be partially due to the additional POST application which increased yields by further reducing competition from Palmer amaranth and increased production costs associated with POST and PRE+POST treatments.

While not statistically significant in all three years, there was a noticeable trend across all three years of the experiment. Utilizing IT in the first year (when Palmer amaranth was the most severe) along with PRE+POST herbicide regime each year provided the highest total net returns when summed across the system. While the NIT system with PRE herbicide regime provided the highest net returns in 2010 and 2011, there was no statistical difference across tillage and herbicide regimes and the increase in net returns was not enough to offset the losses in 2009. Assuming the additional variable costs associated with cotton production, aside from land rent and crop insurance, were $900 \mathrm{US} \mathrm{ha}^{-1}$, only two treatment options (IT/POST and IT/PRE+POST) in 2009 covered the total variable costs. On average, in 2010, revenues were not large enough to cover the total variable costs, while in 2011, revenues were larger due to higher cotton lint yields and, on average, revenues would cover total variable costs associated with cotton production across all tillage and herbicide combinations.
3.3. Cover Crops. As shown in Table 5, the cover crop treatment was only significant in $2011(P=0.0071)$. In 2011, the fallow treatment had the highest net returns and exceeded the net returns to clover and rye treatments by 425 and $365 \mathrm{US} \mathrm{ha}^{-1}$, respectively (Table 6). There was no statistical difference between clover and rye treatments.

Previous research has shown that the use of a high residue rye cover crop as part of a conservation system provides mulching and allelopathic effects that limits weed germination and growth, especially under high biomass levels [21, 29-35]. The rye treatment did not perform as well as expected based on the previous research. In 2009 and 2010, rye biomass amounts were lower than clover, most likely due to lack of fertilization [25]. The average cost of biomass production (cover crop establishment and termination cost divided by biomass output) was higher for rye in 2009 and 2010 (4.48 US $\$ 100 \mathrm{~kg}^{-1}$ and $9.08 \mathrm{US} \$ 100 \mathrm{~kg}^{-1}$, resp.) than for clover (3.35 US $\$ 100 \mathrm{~kg}^{-1}$ and 7.15 US $\$ 100 \mathrm{~kg}^{-1}$ ). Delayed planting of the cover crop also likely reduced the amount of biomass produced in both clover and rye in 2010 and clover in 2011. Due to replanting clover in 2011, the average cost for clover was $16.18 \mathrm{US} \$ 100 \mathrm{~kg}^{-1}$, as compared to 3.66 US $\$ 100 \mathrm{~kg}^{-1}$ for rye.

There were several production challenges within the experiment that may have played an underlying role in the outcome of the study, in conjunction with the treatments. Different results may have been realized if (1) rye treatment had received nitrogen fertilizer each year [25]; (2) schedule of operations was more consistent between years (i.e., date of cover crop planting; date of cotton planting); and (3) operations within year had occurred at the optimal time (i.e., cover crops were planted after December 1 in 2010 and 2011). Inconsistency in the schedule of operations between years and timing within year was largely driven by weather, beyond the control of the researchers, and a situation often faced by cotton producers. Based on these differences, these results are applicable to operations with similar soil types and management decisions, and in years with similar weather. Future research is needed to determine if it is necessary to incorporate these differences into the analysis and, if so, the best way to accomplish this task. Finally, this was a short-term analysis and did not consider the long-term benefits of the adoption of a cover crop and the negative impact of reverting to IT after the long-term use of NIT $[5,36]$.

\section{Conclusions}

Cotton producers in Alabama and across the Southeast and Mid-South are struggling to control Palmer amaranth infestations on their operations. Many producers are turning to cultural management techniques such as IT and cover crops, along with herbicide treatments as part of their weed management system. This study evaluated the influence of tillage, cover crops, and herbicide regimes on net returns from cotton production. The data used were from an experiment conducted at EVS near Shorter, Alabama, in 2009, 2010, and 2011. 
Results indicated that under heavy Palmer amaranth populations IT with a POST or PRE+POST herbicide application had the highest net returns in the first year; however, the economic benefit of IT, across all herbicide treatments, was not statistically significant in 2010 and 2011. For the NIT system, applying a PRE+POST in 2009 and a PRE in 2010 provided the highest net returns. With the exception of 2011, cover crop use did not negatively impact net returns as there was no statistical difference between cover crops and fallow. While this research did not directly address erosion potential due to IT, planting a cover crop immediately following IT would minimize the potential for soil erosion in situations where IT was necessary to control Palmer amaranth. Additional research is needed to further investigate economic impact of using cultural techniques to control Palmer amaranth and other herbicide-resistant weeds in a conservation system.

\section{Competing Interests}

Mention of a trade name, proprietary product, or specific equipment does not constitute a guarantee or warranty by the USDA and does not apply endorsement of a product to the exclusion of others that may be suitable.

\section{References}

[1] United States Department of Agriculture, "National Agricultural Statistics Service (USDA-NASS)," 2014, http:/quickstats .nass.usda.gov.

[2] USDA-NASS, "Appendix B General Explanation and Census of Agriculture Report Form," 2012, http://www.agcensus.usda .gov/Publications/2012/Full_Report/Volume_1,_Chapter_1_US/ usappxb.pdf.

[3] USDA-NASS, “Acreage-June 2014," 2014, http://usda.mannlib .cornell.edu/usda/nass/Acre/2010s/2014/Acre-06-30-2014.pdf.

[4] J. E. Carpenter and L. P. Gianessi, "Economic impacts of glyphosate-resistant weeds," in Glyphosate Resistance in Crops and Weeds: History, Development, and Management, pp. 297312, John Wiley \& Sons, Hoboken, NJ, USA, 2010.

[5] A. J. Price, K. S. Balkcom, S. A. Culpepper, J. A. Kelton, R. L. Nichols, and H. Schomberg, "Glyphosate-resistant Palmer amaranth: a threat to conservation tillage," Journal of Soil and Water Conservation, vol. 66, no. 4, pp. 265-275, 2011.

[6] I. Heap, The International Survey of Herbicide Resistant Weeds, 2014, http://www.weedscience.com.

[7] M. J. Horak and T. M. Loughin, "Growth analysis of four Amaranthus species," Weed Science, vol. 48, no. 3, pp. 347-355, 2000.

[8] P. E. Keeley, C. H. Carter, and R. M. Thullen, "Influence of planting date on growth of Palmer amaranth (Amaranthus palmeri)," Weed Science, vol. 35, pp. 199-204, 1987.

[9] J. K. Norsworthy, G. Griffith, T. Griffin, M. Bagavathiannan, and E. E. Gbur, "In-field movement of glyphosate-resistant Palmer amaranth (Amaranthus palmeri) and its impact on cotton lint yield: evidence supporting a zero-threshold strategy," Weed Science, vol. 62, no. 2, pp. 237-249, 2014.

[10] L. M. Sosnoskie and A. S. Culpepper, "Glyphosate-resistant palmer amaranth (Amaranthus palmeri) increases herbicide use, tillage, and hand-weeding in georgia cotton," Weed Science, vol. 62, no. 2, pp. 393-402, 2014.
[11] S. M. Ward, T. M. Webster, and L. E. Steckel, "Palmer amaranth (Amaranthus palmeri): a review," Weed Technology, vol. 27, no. 1, pp. 12-27, 2013.

[12] T. M. Webster and R. L. Nichols, "Changes in the prevalence of weed species in the major agronomic crops of the Southern United States: 1994/1995 to 2008/2009," Weed Science, vol. 60, no. 2, pp. 145-157, 2012.

[13] A. S. Culpepper, A. C. York, P. Roberts, and J. R. Whitaker, "Weed control and crop response to glufosinate applied to 'PHY 485 WRF' cotton," Weed Technology, vol. 23, no. 3, pp. 356-362, 2009.

[14] A. W. MacRae, A. S. Culpepper, and J. M. Kichler, "Managing glyphosate-resistant Palmer amaranth in Liberty Link cotton," in Proceedings of the Beltwide Cotton Conference, p. 1232, National Cotton Council of America, 2007.

[15] J. Aulakh, A. Price, S. Enloe, E. Santen, G. Wehtje, and M. Patterson, "Integrated palmer amaranth management in glufosinateresistant cotton: I. Soil-inversion, high-residue cover crops and herbicide regimes," Agronomy, vol. 2, no. 4, pp. 295-311, 2012.

[16] J. D. DeVore, J. K. Norsworthy, and K. R. Brye, "Influences of deep tillage and a rye cover crop on glyphosate-resistant Palmer amaranth (Amaranthus palmeri) emergence in cotton," Weed Technology, vol. 26, no. 4, pp. 832-838, 2012.

[17] J. A. Kelton, A. J. Price, M. G. Patterson, C. D. Monks, and E. van Santen, "Evaluation of tillage and herbicide interaction for Amaranthus control in cotton," Weed Technology, vol. 27, no. 2, pp. 298-304, 2013.

[18] D. T. Smith, R. V. Baker, and G. L. Steele, "Palmer amaranth (Amaranthus palmeri) impacts on yield, harvesting, and ginning in dryland cotton (Gossypium hirsutum)," Weed Technology, vol. 14, no. 1, pp. 122-126, 2000.

[19] J. W. Weirich, D. R. Shaw, M. D. Owen et al., "Benchmark study on glyphosate-resistant cropping systems in the United States. Part 5: effects of glyphosate-based weed management programs on farm-level profitability," Pest Management Science, vol. 67, no. 7, pp. 781-784, 2011.

[20] W. D. Shurley, A. R. Smith, S. Culpepper, and R. L. Nichols, "Economic analysis of heavy rye cover crop to control glyphosate resistant Palmer amaranth in cotton," in Proceedings of the Beltwide Cotton Conference, p. 400, National Cotton Council of America, New Orleans, La, USA, January 2014.

[21] A. J. Price, K. S. Balkcom, L. M. Duzy, and J. A. Kelton, "Herbicide and cover crop residue integration for amaranthus control in conservation agriculture cotton and implications for resistance management," Weed Technology, vol. 26, no. 3, pp. 490-498, 2012.

[22] W. F. Lazarus, Machinery Cost Estimates, University of Minnesota, Minneapolis, Minn, USA, 2014.

[23] Alabama Cooperative Extension System (ACES), "Alabama enterprise budget summaries," 2014, http://www.aces.edu/ agriculture/business-management/budgets.

[24] Mississippi State University (MSU), "Cotton 2014 Planning Budgets," Mississippi State University, 2014, http://www.agecon .msstate.edu/whatwedo/budgets/docs/MSUCOT14.pdf.

[25] A. Clark, Ed., Managing Cover Crops Profitably, Sustainable Agriculture Network, Beltsville, Md, USA, 3rd edition, 2007.

[26] C. W. Bednarz, W. D. Shurley, and W. S. Anthony, "Losses in yield, quality, and profitability of cotton from improper harvest timing," Agronomy Journal, vol. 94, no. 5, pp. 1004-1011, 2002.

[27] W. T. Pettigrew, "Improved yield potential with an early planting cotton production system," Agronomy Journal, vol. 94, no. 5, pp. 997-1003, 2002. 
[28] W. T. Pettigrew, W. T. Molin, and S. R. Stetina, "Impact of varying planting dates and tillage systems on cotton growth and lint yield production," Agronomy Journal, vol. 101, no. 5, pp. 11311138, 2009.

[29] J. P. Barnes and A. R. Putnam, "Rye residues contribute weed suppression in no-tillage cropping systems," Journal of Chemical Ecology, vol. 9, no. 8, pp. 1045-1057, 1983.

[30] J. R. Teasdale, C. E. Beste, and W. E. Potts, "Response of weeds to tillage and cover crop residue," Weed Science, vol. 39, pp. 195199, 1991.

[31] J. R. Teasdale and C. L. Mohler, "The quantitative relationship between weed emergence and the physical properties of mulches," Weed Science, vol. 48, no. 3, pp. 385-392, 2000.

[32] D. W. Reeves, A. J. Price, and M. G. Patterson, "Evaluation of three winter cereals for weed control in conservation-tillage nontransgenic cotton," Weed Technology, vol. 19, no. 3, pp. 731736, 2005.

[33] A. J. Price, D. W. Reeves, and M. G. Patterson, "Evaluation of weed control provided by three winter cereals in conservationtillage soybean," Renewable Agriculture and Food Systems, vol. 21, no. 3, pp. 159-164, 2006.

[34] A. J. Price, D. W. Reeves, M. G. Patterson et al., "Weed control in peanut grown in a high-residue conservation-tillage system," Peanut Science, vol. 34, no. 1, pp. 59-64, 2007.

[35] A. J. Price, M. E. Stoll, J. S. Bergtold et al., "Effect of cover crop extracts on cotton and radish radicle elongation," Communications in Biometry and Crop Science, vol. 3, no. 1, pp. 60-66, 2008.

[36] D. J. Boquet, R. L. Hutchinson, and G. A. Breitenbeck, "Longterm tillage, cover crop, and nitrogen rate effects on cotton: plant growth and yield components," Agronomy Journal, vol. 96, no. 5, pp. 1443-1452, 2004. 


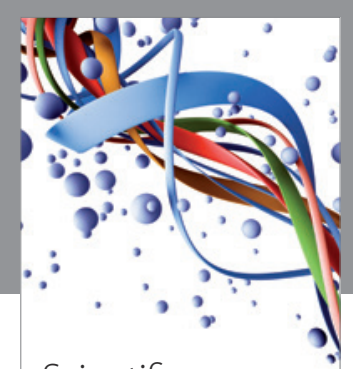

Scientifica
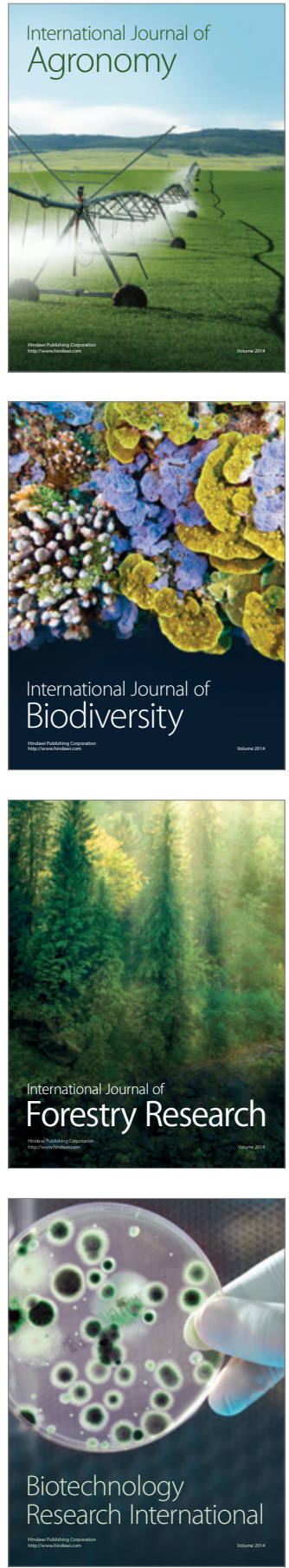
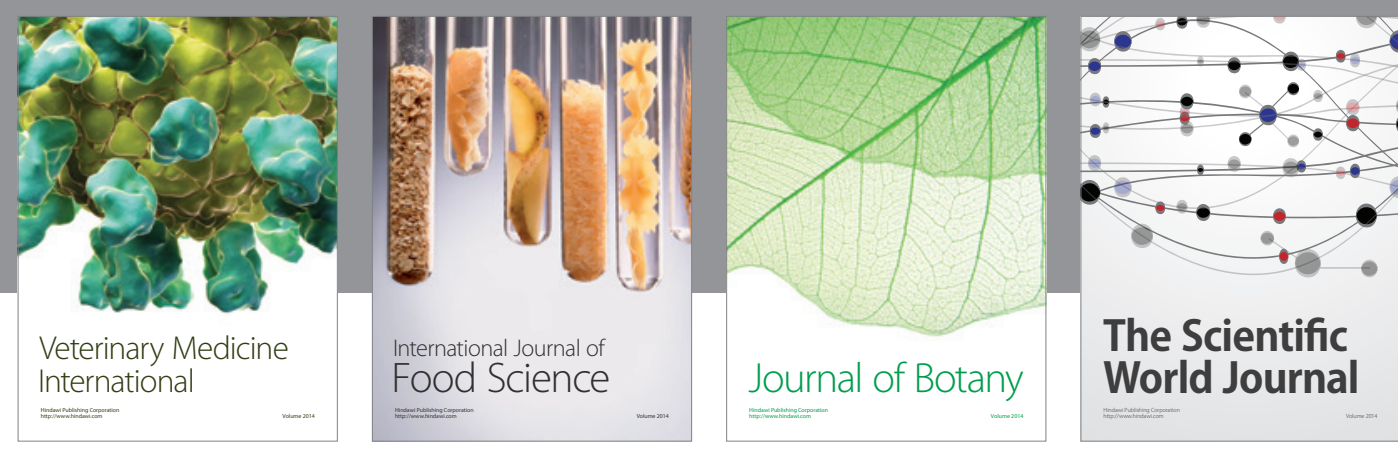

The Scientific

\section{World Journal}

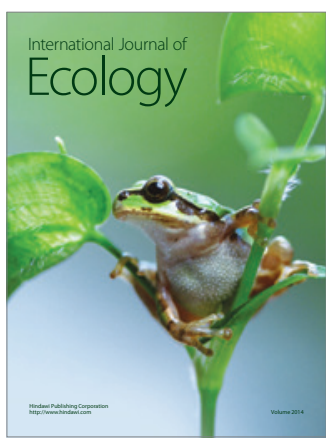

\section{Hindawi}

Submit your manuscripts at

http://www.hindawi.com
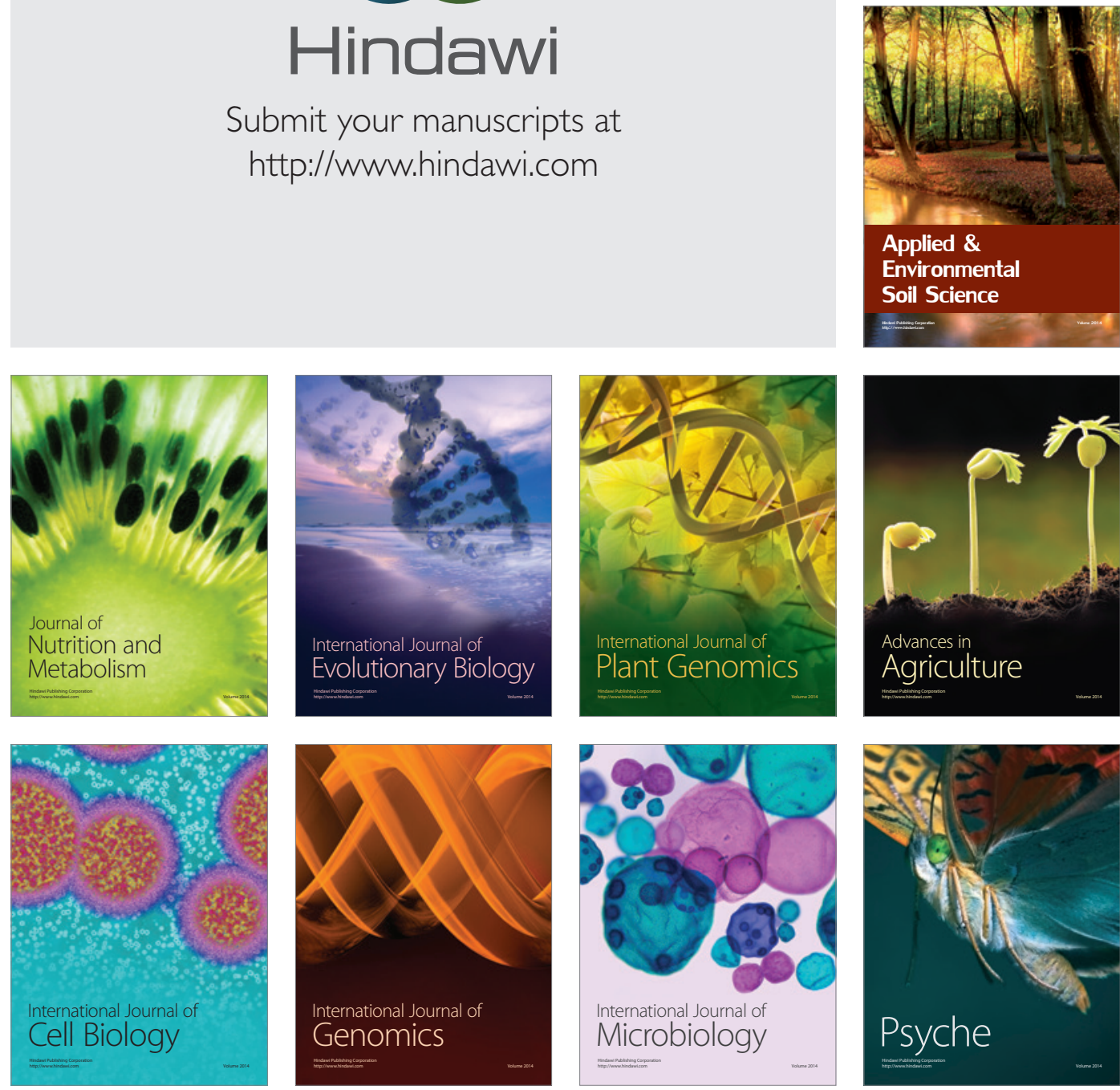
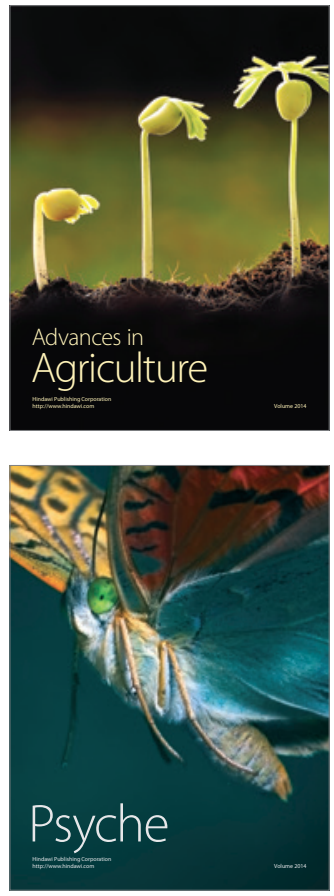